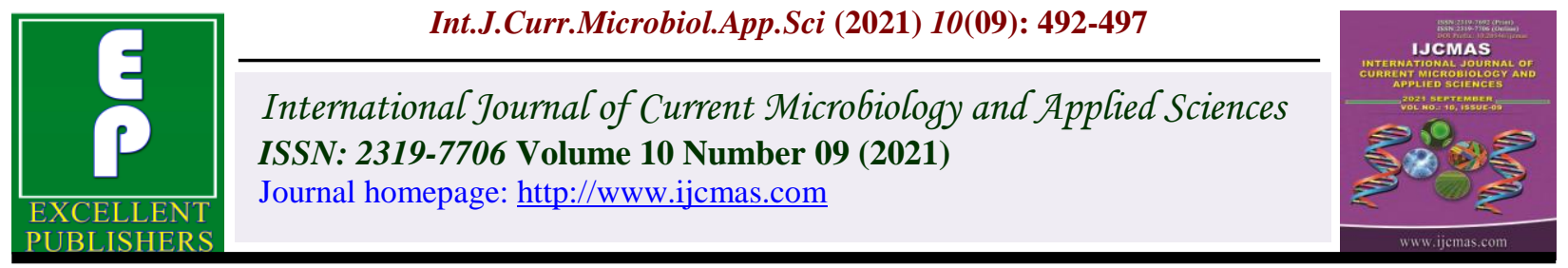

Review Article

https://doi.org/10.20546/ijcmas.2021.1009.057

\title{
Biopolymers: Impact of Polymers that Replace Conventional Plastics, An Option for a Sustainable Future
}

\author{
A. E. Andrango, J. E. Apugllon, A. D Durán, P. J. Nazareno and Carlos Jácome
}

Departamento de Biotecnología, Escuela de Ingeniería Agroindustrial, Universidad Estatal de Bolívar. Facultad de Ciencias Agropecuarias, Recursos Naturales y del Ambiente. Código Postal: 020150. Av. San Simón Km. 2.5. Guaranda-Ecuador

*Corresponding author

Keywords

Plastic, biopolymer, biodegradable, production, raw material, bioplastics

Article Info

Accepted:

20 August 2021

Available Online:

10 September 2021

\section{A B S T R A C T}

The work carried out focuses on the importance and characteristics of bioplastics, which is why the bibliographic sources consulted recall that the plastic manufactured from biopolymers has been increasing due to its practicality and in supporting the reduction of pollution of solid waste worldwide. Viable alternatives are currently being sought to replace packaging and coatings made from non-renewable raw materials, as these cause millions of tons of waste each year, damaging the environment. The production process of biodegradable plastics has a certain resemblance to the production of conventional plastics, it consists of a mixer of raw materials with additional components, for a subsequent blowing and sealing, passing through a quality control. One of the problems with conventional plastics is that they are manufactured from raw materials obtained from non-renewable resources, which each day becomes scarcer and therefore more expensive. Also the problem of persistence in the medium for very long times, which cause them to occupy space in sanitary landfills, which are causing problems in the country due to lack of space.

\section{Introduction}

The pollution of plastics has a high impact on the environment, as time progresses the situation of uncontrolled use worsens more, biopolymers help to counteract the large amounts of plastic waste because it degrades in less time compared to a plastic obtained from petroleum derivatives. Although it is in the 30 s of the last century when plastics began to be generated, it was not until two decades later that their use began to permeate in all areas of our lives (Santillán, 2018).

The first discovery of a polymer dates back to the middle of the 19th century, when Luis 
Pasteur discovered dextrose as a microbial product in wine, which Van Tieghem later identified that the bacterium Leunostoc mesenteroides is responsible for the formation of dextrose. This discovery was followed by the finding in 1886 that cellulose is produced by bacteria. Time after the discovery of these exopolysaccharides. The first intracellular reserve polymers such as the polyamide cyanophycin were discovered in cyanobacteria; and 40 years later the polyhydroxybutyrate polyester in Bacillus magaterium. Most of the bacterial polymers used in industries were found in the middle of the 20th century such as (algin, xanthan, polyg-glutamate, polyphosphate). Shortly after the discovery of several biopolymers, the activities of their biosynthetic enzymes were described precursors that were used to obtain some details on the metabolic pathways for the formation of the biopolymer (Castro, 2006). The conscientization on the use of bioplastics significantly reduces environmental pollution for DiGregorio, (2009) approximately 140 million tons are produced annually, derived from oil.

Biopolymers have accompanied humanity since it exists. They have made part of their daily needs as fundamental as food and clothing. Some of them, such as DNA or RNA, are the foundation and foundation of life, as well as proteins, one of the functional building blocks of life at the molecular level (Peres, 2010). The objective of this bibliographic review is to provide researchers with extensive and accurate information on the production of bioplastics. One of these highly studied natural biopolymers is starch, since it is very abundant and cheap to obtain. Its use can play a decisive role in the substitution of synthetic plastics, thus reducing the problem of accumulation of plastic waste and reducing dependence on the excessive use of oil (Rosales, 2016). The Ecuadorian agribusiness sector generates residues of interest that are useful given their composition and the possibility of processing to give them added value, most of them contain starch or lignocellulosic compounds that, when applying physical, chemical or biotechnological transformations, can be used as raw material, filler material or precursor of bioplastics (María Riera, 2018).

\section{Bioplastics}

Bioplastics are made from vegetables and fruits using polymers that are easy to biodegrade and are non-toxic. The raw material for the manufacture of this product has to be composed of cellulose and starch (Lema, 2021).

\section{Bioplastics properties}

Bioplastics made from wheat gluten, using glycerin and water as plasticizer and $\mathrm{KCl}$ (potassium chloride) as active agent. For an improvement in the properties of water absorption capacity and $\mathrm{KCl}$ release rate of these bioplastics, the effect of thermoforming temperature, the effect of the plasticizer, was studied, replacing glycerin and water with polyethylene glycol (PEG) with different molecular weights and the addition of different organic acids as structure modifying agents (Gómez, 2013).

Various authors indicate the requirements they need meet the packaging for agricultural products to meet the needs of agribusiness.

For example, (Khan et al., 2016) mention that packaging based on polymeric materials must limit or delay microbial growth, in addition to providing protection against chemical, biological and physical contaminants, being a good barrier against gas exchange, provide a decorative appearance and facilitate marketing and maintain the quality of the agricultural product, among others. For some decades 
now, problems related to the accumulation of non-biodegradable plastics from petroleum in the environment, and the rapid depletion of the natural resources used in their production, have motivated the investigation of alternatives to non-degradable polymers. In such a scenario, biodegradable plastics offer the best solution to the environmental hazard posed by conventional plastics.

\section{Types of bioplastics}

According to Zhao, (2020) bioplastics are classified as: Bio-based and nonbiodegradable, which are made from bioethanol.

Biobased and biodegradable, these materials are mainly made from Polyhydroxyalkanoates and starch. Gómez and Yory (2017) refer to the fact that the raw materials for the production of biobased and biodegradable plastics are from animals, plants and microorganisms. On the other hand, Peplow (2016) alludes that this matter can also be of plant origin such as sugar, corn, starch, among others.

From oil and biodegradable, According to Badia, Gil \& Ribes (2017), these polymers are especially composed of organic molecules of oil with nitrogen, oxygen and sulfur. Its biodegradation will depend on the proportions that each bacterium entails

\section{Classification of bioplastics}

\section{Advantages of bioplastic}

According to Ghada A., (2018), the main advantages of using bioplastics are;

Reduces greenhouse gases (carbon footprint).

Unlike plastics, these do not include phthalates or bisphenol that are harmful to health. They do not affect the organoleptic characteristics of food.

They reduce plastic waste that causes a greater proportion of environmental pollution. There is energy savings in production.

\section{Plastic}

According to Bontempi (2017) Plastics since their inception have been mainly made from oil, through polymerization reactions. These plastics have been used in the elaboration of multiple products at an industrial and artisanal level, destined for different purposes (Bilo, et al., 2018). Because conventional polymers are composed of antioxidants, in addition to a mixture of harmful chemicals, pigments and additives to decrease density, this has become a serious problem for environmental pollution and for the health of living beings (Hahladakis et al., 2018; Hermabessiere et al., 2017).

\section{Characteristics of Plastics}

One of the basic characteristics of plastics is their resistance to degradation under the action of natural physical, chemical or biological elements. This gives them a very long permanence after being released into the environment, turning what is an advantage in use into a serious environmental problem. The only way to permanently remove fossil plastic waste is to incinerate it. Solution that is not such, by releasing also harmful combustion residues.

As a consequence, permanent contamination of the environment by these plastics is a growing concern (Pacheco, 2018).

\section{Plastic pollution}

Carriel (2018) states that "this material has been present since 1950, it had a high degree of acceptability due to its low cost and its 
ability to adapt to any product, as time passed the demand was much higher and in 1980 the sale of many materials exceeded including glass and metals ". There were no treatments to recycle each used container, it was for this reason that they began to be thrown into the garbage cans, on the other hand, they were burned and those that were still in good condition were reused, because of floods the plastics arrived at the sea each time to a greater extent affecting marine life, in the long run, plastic surfaces have been created on the sea exceeding $1,000,000 \mathrm{~km}^{2}$, (the size of Ecuador is one third of this island) $80 \%$ of said pollution comes from the land, animals unconsciously ingest this material causing death either by drowning, by being trapped due to lack of food, many cause serious injuries (Lema, 2021).

Oropeza et al., (2016) suggest that plastic containers are the main source of contamination and the highest percentage is food packaging.

\section{Importance of starch in bioplastics}

Starch is a complex polysaccharide, which is stored in the form of granules, with different sizes, chemical composition and physical characteristics, which vary depending on the source from which it comes (Arias, 2019). It is a complex and highly organized semicrystalline structure, composed of glucose polymers: amylose and amylopectin, with the synthesis of the amylose component found within the amylopectin matrix. From the point of view of its use as a polymeric material, two different uses can be distinguished: as a polymeric matrix in the form of thermoplastic starch and as a nano-filler in the form of nanocrystals (Sessini, 2017). Previous experiences have shown that it is possible to obtain plastic films. Flexible biodegradable, from cassava and pectin starch, corn cob, potato, banana and other polymers, as well as patents for thermoplastic starch production processes (Riera M., 2019).

Regardless of where the starch comes from (corn, wheat, cassava, potato or banana), there are two methods used for its extraction: dry milling and wet milling. Specifically for corn, dry grinding is used in an artisanal way and wet grinding is used by large companies to refine and improve the products obtained from this plant, the main purpose being to obtain starch (FAO, 2020).

\section{Importance of corn starch}

Gálvez, (2016) elaborated bioplastic based on corn starch, it was shown that these can compete with plastics made based on petroleum because they have appropriate qualitative and physical characteristics, in addition to a short degradation time of approximately 90 days .

Corn (Zea mays L.) has become one of the most consumed cereals in the world, with multiple applications for both nutritional and industrial purposes. It is used for the production of starch, since the grain is made up of approximately 70 to $75 \%$ of it. Hence the reason for being used in the production of plastics, this can replace plastic products based on petroleum and its derivatives that are non-renewable resources (Grande, 2017).

Another work where corn starch was used using glycerol as a plasticizer, the mechanical properties of bioplastics obtained with three commercial plastics derived from petroleum were compared. The results showed that the biopolymers produced have mechanical properties with lower values than the plastics derived from petroleum, however, when using $35 \%$ glycerin and a $\mathrm{pH}$ of 5 or 7 , the percentage of elongation is comparable to a plastic derived from petroleum (Narváez, 2016). 


\section{Classification of polymers}

\section{According to its origin}

\section{Natural}

They can occur in nature (plant and animal kingdom), for example: cellulose, natural rubber, resins, starch, among others.

\section{Semisynthetics}

Obtained by chemical transformation of natural polymers, without appreciably destroying their macromolecular nature, for example: artificial silk obtained from cellulose.

\section{Biodegradable plastics}

PHAs are polymers of hydroxyalkanoic acids that some bacteria, archaea and micro algae synthesize and accumulate intracellularly as reserve material, to be used later as a source of carbon and energy. These polymers accumulate in the form of granules in the microbial cytoplasm, and once extracted and purified, they present physical properties similar to petroleum-derived plastics.

Plastics prepared from PHAs are therefore biodegradable plastics of microbial origin, similar to those derived from petroleum, but produced from renewable carbon sources, and which have great potential for use in applications ranging from manufacture of disposable products for common use, up to that of biomedical and pharmaceutical products with high added value (Gómez, 2013).

Bioplastics made from polymers of renewable raw materials that are biodegradable in the environment, are part of the reduction of the problems that are increasing in waste management, the consumption of conventional plastics obtained from fossil sources is causing serious problems environmental, biopolymeric plastic materials continue to grow, bioplastics are a "green" and sustainable alternative, they are more ecological since they reduce the carbon footprint and the use of a fuel such as oil thus contributes to the fight against global pollution. The chemical and industrial design of the production process is a clear example that the waste of an industry can be used to develop new products through chemical processes.

\section{References}

Arias, M. (2019). Obtención del Almidón de la Alocacia Macrorrhiza y Cuantificación del Oxalato de Calcio. . Instituto Tecnológico Superior Calazacón.

Badia J., G. O. (2017). Propiedades a largo plazo y fin de vida útil de los polímeros a partir de recursos renovables. . Polym. Degrad. Stab., Vol. 137, pp. 35-57.

Bilo F, P. S. (2018). Un bioplástico sostenible obtenido a partir de paja de arroz. Elsevier. DOI: 10.1016 / j.jclepro.2018.07.252.

Bontempi, E. (2017). Estudio de caso de sustitución de materias primas: sustitución de rellenos naturales en compuestos plásticos. Springer Briefs en Appl. Sci. Technol 2.

Carriel, M. (2018). Plásticos en el mar. Obtenido de Instituto Nacional de Pesca IPIAP.

Castro, A. (2006). Biopolimeros a partir de microorganismos. 1-8 p .

DiGregorio, B. (2009). Biobased Performance Bioplastic: Mirel. Chemistry \& Biology. $\mathrm{N}^{\circ} 16$, pp.

Gálvez, A. (2016). Elaboración De Plástico Biodegradable A Partir Del Almidón Extraído Del Maíz (Zea mays). Universidad de San Carlos de 
Guatemala $10-25 \mathrm{p}$.

Ghada A., A. M. (2018.). Una descripción general de los aditivos químicos presentes en los plásticos: migración, liberación, destino e impacto ambiental durante su uso, eliminacióny reciclaje.

Gómez S, \&. Y. (2017). Aprovechamiento de recursos renovables en la obtención de nuevos.

Gómez, G. (2013). Desarrollo de bioplásticos a partir de subproductos agroalimentarios con aplicaciones en envases y matrices de difusión.

Grande, T. (2017). Producción y procesamiento del maíz en Colombia. . doi.org/10.21500/22563202.604.

Hermabessiere L., D. A. (2017). Ocurrencia y efectos de los aditivos plásticos en los entornos y organismos marinos: una revisión. Chemosphere 182, $781 \mathrm{mi} 793$. doi.org/10.1016/j.chemosphere.2017.0 5.096.

Khan, B. (2016). Khan, N M B, Samin, G. Y. Jahan, Z. Almidón termoplástico: un posible material de envasado de alimentos biodegradable: una revisión. Revista de Ingeniería de Procesos de Alimentos, 40 (3), e12447 . DOI: doi: $10.1111 /$ jfpe. 12447.

Lema, E. (2021). Bioplásticos a partir de residuos del cacao, una alternativa para mitigar la contaminación por plástico. Ingeniería e Inovación ISSN:23460466.

María Riera, S. M. (2018). Residuos agroindustriales generados en Ecuador para la elaboracion de bioplasticos . Vol. 17 Núm. 3 (2018).

Narváez, M. (2016). Optimización de las propiedades mecánicas de bioplásticos sintetizados a partir de almidón. Quito: USFQ, 2016.

Oropeza R., M. I. (2016). Películas biodegradables a base de almidón: propiedades mecánicas. Ciencia y Tecnología de Alimentos, 65-93. .

Pacheco, M. (2018). Bioplásticos - Usos generales y agrarios.

Peplow, M. (2016). La revolución de los plásticos: cómo los químicos están llevando los polímeros a nuevos límites. . Naturaleza. Vol. 536, No. 7616, pp. 266-268.

Peres, L. (2010). Biopolimeros como una alternativa de sustitución de polimeros sintéticos . . (Tesis de grado) Instituto politécnicno nacional .

Rosales, A. (2016). Obtención de biopolímero plástico a partir del almidón de malanga (Colocasia esculenta), por el método de polimerización por condensación. (Tesisi de grado) Universidad Nacional Autónoma de Nicaragua.

Santillán, M. (2018). Una vida de plástico. Mexico : Universidad Autónoma de México .

Sessini, V. \&. (2017). Revista de plásticos modernos. .ISSN 0034-8708.

Zhao X, K. C. (2020). Reducir la brecha para el uso de bioplásticos. Reinar. Sci. Technol. 2020, 54, 4712-4732.

\section{How to cite this article:}

Andrango, A. E., J. E. Apugllon, A. D Durán, P. J. Nazareno and Carlos Jácome. 2021. Biopolymers: Impact of Polymers that Replace Conventional Plastics, An Option for A Sustainable Future. Int.J.Curr.Microbiol.App.Sci. 10(09): 492-497. doi: https://doi.org/10.20546/ijcmas.2021.1009.057 